\title{
Penciptaan Animasi "Upload" Dengan Teknik Animasi Digital 2D
}

\author{
Gayus Hendrianto \\ Infinite Framework Studio \\ e-mail: gayushendrianto@gmial.com
}

\begin{abstract}
Abstrak
Animasi memiliki kesan kepada penonton bahwa animasi itu menghibur, unik, lucu, dan cenderung diperuntukkan untuk anak-anak. Pada perkembangannnya animasi kini tidak hanya dibuat untuk anak-anak saja, namun animasi juga dibuat untuk konsumsi kalangan remaja, dewasa dan semua umur.

Karya Animasi "Upload" ini merupakan sebuah karya reflektif tentang kehidupan generasi muda masa kini yang mengalami ketergantungan dengan Internet. Dengan sentuhan komedi, paparan visual yang menarik kiranya dapat menghibur dan berkesan pada penonton.

Udin adalah karakter utama dalam karya animasi ini. Udin adalah seorang pemuda berumur 25 tahun yang beberja sebagai pekerja freelance, pada suatu hari ia harus mengirimkan pekerjannya kepada kliennya melalui email. Ketika ia menguduh pekerjaannya kendala sinyal internet membuat pekerjaan Udin selalu gagal ter-upload. Segala cara dilakukan Udin supaya pekerjaan dapat terkirim sesuai pada deadline.
\end{abstract}

Kata kunci: Animasi, Upload, 2D

\section{Abstract}

Animation has the impression to the audience that the animation is entertaining, unique, funny, and tends to be reserved for children. In the development of animation is now not only made for children only, but animation is also made for consumption among adolescents, adults and all ages.

The "Upload" Animation Works is a reflective work on the lives of today's young people who are dependent on the Internet. With a touch of comedy, eye-catching visual exposure may be entertaining and memorable to the audience.

Udin is the main character in this animated work. Udin 25 years old young man who is freelance worker, one day he has to send his work to his client via email. When he accuses his job of internet signal constraints making Udin's work always fails to upload. Every way Udin can do so the work can be sent according to the deadline.

Keywords: Animation, Upload, $2 D$ 